\title{
WHAT AMERICANS MUST DO TO MAKE AN EXPORT BUSINESS ${ }^{1}$
}

\author{
By Jamrs W. Van Clenve, St. Louis, Mo.
}

President National Association of Manufacturers of the United States of America.

Mr. Chairman and Gentlemen of the Convention:

As I look around this hall this afternoon and see the interests which are represented here I am reminded that commercially the United States touches the outside world at many points, and touches it intimately. Where are now the men and the interests that once demanded, "What do we care for Abroad?" The program of this convention is a response to that challenge.

Industrially speaking, Abroad might have seemed to mean little to the average American of 1857,1867 or 1877 . But it means much to us of 1907 . And it will mean still more to the Americans of I9I7 and 1927. We are richer than we were in those earlier and more boastful days. In number as well as in volume our industries have expancled. But every step in this expansion makes an additional demand upon us to open new markets in other countries for our products.

Somebody has said that Nature wrote the "most favored nation" clause in the fiat which created the United States. It is easy for us who are in this hall, and who know what brought us here, to grasp the force of this aphorism.

The arithmetics of your boyhood's days and mine are obsolete. The big figures which thirty or forty years ago described the resources and advances of the United States are only the units of the sum which tell the story of its activities to-day. Hundreds of thousands and millions have dropped out of our industrial mathematics. We have to deal in billions now.

In the year which ended two weeks ago the products of our mines went up close to the $\$ 2,000,000,000$ mark, and the earnings of our farmers were almost $\$ 7,000,000,000$. Our mills and factories paid $\$ 3,500,000,000$ to their employees, and these produced

${ }^{1}$ An address before the Convention for the Extension of Foreign Commerce, held at Washington, D. C., January $14-16,1907$.

(470) 
$\$ 15,000,000,000$ of finished goods. The country's foreign trade passed the $\$ 3,000,000,000$ line, and our domestic commerce amounted to more than $\$ 25,000,000,000$.

But these big figures warn us to look outside of our own country for new outlets for our surplus. To a larger and larger extent every year home production outruns home consumption. The domestic market is our chief reliance, and always will be, but we must get new foreign markets for our surplus.

One way of extending our foreign trade is through the creation of an adequate merchant marine. Subsidies by the national government, wisely distributed and regulated, will put our commercial flag again on the seas. The government ought to extend to ship builders and ship owners the same sort of protection as that by which our miners and mill owners have made the United States the greatest mineral-producing and textile-manufacturing countiry on the globe.

But we need something more than a merchant marine to enable us to win new markets, or to hold those which we now have. We must learn the world's needs and tastes in merchandise, and set to work intelligently to supply them. This is particularly true of South America. Partly through better shipping facilities, but chiefly through a better knowledge of the people and their wants, England and Germany are far ahead of us in their trade with South America. In 1906 we bought twenty per cent of all the merchandise which South Ámerica exported, but we sold to her only twelve per cent of what she imported.

Although we produce most of the things which Latin-America needs, we are allowing our British and German rivals to beat us in trade with that portion of the world. In the aggregate of our manufactures we are far ahead of any other two countries combined, and our lead is rapidly increasing. In 1906 we exported $\$ 603,000$,oo of manufactures, but very little of these went to the people south of the Caribbean.

The government here in Washington is doing something toward marking out paths by which, with our co-operation, we can extend our trade abroad. Secretary Root is improving the consular service, and is equipping our government agents at the world's chief importing points to learn those people's needs, and to study how we can supply them. On application by any American manufacturer, Secretary Straus' Department of Commerce and Labor will send 
samples of goods which England, Germany and our other rivals sell in China, Japan, South Africa, Egypt and South America.

We must encourage the government to broaden this work, so as to apply it to all countries and to all important products which we sell. But the practical work of extending our trade has to bc done by us as individual manufacturers and exporters. Our own special representatives on the ground must utilize and supplement the work done by the government's agents.

Even with the recent advances in our government's methods of ascertaining the world's needs and tastes, the German government is ahead of us. And the work done by the special agents of Germany's individual exporters leaves us still farther behind. They go to the importing countries with a linguistic and technical knowledge immeasurably beyond that of the average American promoter, and they pursue their work with a skill, an energy and a persistence which our representatives do not approach. Our representatives must be equipped to talk the tongue of the people with whom we seek to win trade, must learn the sort of goods which they want, must make our credits agree with their customs and convenience, and we must very carefully avoid any airs of superiority over them. In every one of these requirements we have been lacking hitherto.

As a people we Americans have inherited from England some good qualities and a few bad ones. One of the bad traits is a feeling of superiority over the rest of the world. This has led us to imagine that our language, governmental system, business methods and general industrial and financial schemes are better than those of any other country. Now, on many points, our language may serve us better than any other language would, but in dealing with most of the other countries outside of England and her possessions, our language needs to be supplemented by the tongue of those people.

In the lapse of time, and under the stress of some hard knocks, England has given up most of her old air of self-sufficiency. We must also do it. This is imperative on us if we want to hold our own in the face of the competition which the other great industrial countries are putting up. We must learn that the world may be able to teach us some things which would be of value to us.

In shaping our business methods to meet our competitors abroad we need to be particularly alert and open-minded. In a reasonable 
degree self-confidence is good, but egotism is bad for a country as well as for an individual. Especially must we grasp the truth that while airs of superiority over the rest of the world may not harm us when we want to buy, they must be dropped when we want to sell.

We were all startled nine years ago when the Cuban war threw Porto Rico and the Philippines on our hands, ended the United States' idyllic exclusiveness, and cast us into the current of the world's political activities. But Dewey's guns at Manila Bay sounded for us no sharper portent than do the whir of our industries as they break through their continental isolation. The deluge of products from our mines and mills warns us that the home consumer is no longer adequate, and that hereafter we must struggle with the rest of the industrial countries for dominance in the world's markets. Neither industrially nor politically can the United States go back to its old isolation. Nor would it go back if it could.

Government subsidies will help us to create a merchant marine. And a merchant marine, reinforced by intelligent and active agents in the foreign trade centers, will help us to gain new markets. But we will not be able to hold those markets unless we strengthen our industries at home so that adversity, in its periodical swings round the globe, will, as compared with the rest of the countries, strike us latest and lightest, and leave us soonest.

Nature has treated us Americans magnificently. She gave us a climate, a soil and an abundance and variety of minerals and watercourses for quick and easy communication between the different sections which make our territory potentially the richest spot on the globe. But Nature warns us that she helps those only who help themselves. She tells us plainly that climate, soil, minerals and watercourses are merely tools for those who can use them. All these were here through the ages in which the Indian occupied this continent, but they profited him nothing. The Indians whom Columbus met had made no important advances over the Indians who were here a score of centuries earlier when Columbus' ancestors were laying the foundations of the Roman empire.

The United States has outgrown its transportation facilities. We need not only more double and quadruple railway trackage, but more mileage of main track. Our waterways must be improved so that we can adequately utilize our many physical advantages in 
that direction. For at least two reasons we need the use of our rivers and lakes to the utmost possible extent-so as to get the ready communication which the railways, single-handed, cannot furnisi, and also to keep down railway rates.

To a considerable degree we have utilized Nature's favors. One of the ways in which we did this was through tariffs which have protected nearly every important interest which needs protection. But discovery, invention and alterations in fashions change industrial conditions, so that tariffs need revision from time to time.

In an address before the Boston Home Market Club two months ago I pointed out some of the reasons why the Republican party, in the national convention of 1908, should pledge itself to revise the tariff immediately after the inauguration of the President in I909, providing the Republicans elect that President, as I believe they will. I also gave reasons why that President, if a Republican, should call Congress in session to revise it just as he stepped into office, as President McKinley did in I897. Elections will then be a long distance off, the demagogues will be silenced, business conditions and not politics will dictate the changes, the revising will be done speedily and sanely, and the trade disturbance which tariff changes always bring will be light and will end quickly.

As an important preliminary to tariff revision, Congress should, either in the present session or early in the term which begins next December, authorize the appointment of a commission representing both parties and many interests, to go over the tariff, schedule by schedule, and recommend changes wherever desirable. President Roosevelt has a larger supply of good naterial from which to select such a commission than President Arthur had for the one which he appointed in 1882 .

This commission, like Arthur's, could get the views of experts of all sections and of many callings. It could consider the question of reciprocity and of maximum and minimum tariff rates in all their aspects. Such a body could render an even greater service, by its report, to the Congress which would meet in extra session in March, 1909, than Arthur's commission did to the Congress which expired in 1883 .

We must make better goods than our European competitors. We must improve our methods so that we can sell those goods as cheaply as our competitors sell inferior goods, or cheaper. We must 
do this notwithstanding the lower prices which Europe's employers pay for labor. To accomplish this we will have to revise the tariff at the right time and in the right way. And we will have to give our labor the highest possible skill and efficiency. I have already mentioned what I think is the right way and time to revise the tariff.

Expressed in terms of day's work and dollars and cents, what is called cheap labor may actually be dear labor. We must equip our laborers to do more work than the Europeans do in the same length of time, and do it better.

To this end we should establish manual training departments in all our public schools, in which boys, beginning at the age of to or II, could learn to handle all the tools used in the ordinary mechanical trades, and we should provide trade high schools in which boys who pass through the manual training branch of the primary schools could become first-class mechanics.

For at least two reasons the United States needs such school training in the industries. The labor unions limit the apprentices to very small numbers in most of the great trades, and prohibit all apprentices in some of them. The boys who get this sort of training in the schools would more than supply the lack of apprentices, and would give our industries the new workers which they need. And these would acquire a skill, a readiness, an initiative and a general intelligence far above the grade of the average worker who served an apprenticeship in the ordinary way.

All our great industries are in urgent need of additional skilled labor. Secretary Straus shows us one way of getting it. He points out that through any of our state boards we can import it without violating the contract labor law passed by Congress long ago. But I prefer to create these skilled laborers at home. In versatility and in general adaptability to new conditions the average American mechanic surpasses the average European in his calling. By a proper training in the mechanical arts in our public schools we can get an equipment for our workers which will place our industries far in advance of those of our European rivals.

Many of the labor unions will oppose this policy of training the youth of our land to do the skilled work which is waiting to be done, and to get the high wages which we stand ready to pay for it. The labor unions constitute only a tenth of the workers of the 
United States, and the proportion of oppressive labor organizations is steadily and rapidly decreasing.

As against the narrowness and the arrogance of the labor unions we must place the well being of the rising generation of Americans whom the unions would shut out from the profitable employment which they seek. And we must also consider the wishes of the great masses of our workers and the prestige and prosperity of our country, all of which are assailed by the labor unions' proscriptive policy.

A few weeks ago, in Chicago, I addressed the Citizens' Industrial Association of America on the necessity of establishing industrial peace--of peace between the employer and the worker, whether the worker belonged to a labor union or not, on the basis of equal and exact justice for all.

As I look around this hall to-day, and see the representatives of all the great trade organizations gathered here to devise means to extend our commerce abroad, I am more than ever impressed with the necessity for industrial peace among us.

The peace is even more necessary to the worker than it is to the employer. Unless we can open larger and larger markets abroad for our constantly increasing surplus of manufactures, many of our mills must, stop. And our manufacturers and exporters will certainly not be able to compete successfully with our foreign com. petitors for the new markets if we are exposed to a fire in the rear.

In time of abounding prosperity like the present we should prepare for adversity. We cannot altogether prevent the failure of the crops on which, to a large degree, our business activity dcpends. Droughts will come from time to time. But science is arming farmers with weapons which make droughts less disastrous than formerly. Discovery, invention and intelligent precaution are making farming less a hazard than it used to be, and more of a calling on which forecasts can be made with some confidence from year to year. We are making two blades of grass grow where only one grew before.

Crop failure is still a menace to general business in the Uniter States, but this menace is not quite so portentous as it was once. Nevertheless, there is an especial need for conservatism and intelligent precaution in the business world in these days of activity when all our great industries and interests are scoring new "high- 
ests." Under any sort of a financial system panics will come sometimes, so long as hope, cupidity and credulity lure men into dangerous paths. Panics have a habit of coming with considerable regularity. They were here in I8I8, I837, I857, 1873 and I893. All arrived unexpectedly. Under the twenty-year law of periodicity another panic would be due in I9I3. Some of our prominent men are predicting that a panic will come earlier than that time.

By avoiding all sorts of extravagances and vulgar display in our business and in our homes; and by refusing to discount the future too much or to expand our enterprises too far with borrowed money, we can do much toward postponing panics, and also toward diminishing their disasters when they come.

We must keep our political and our commercial conscience above suspicion. All quack political remedies for real or imagined ills like government ownership of railways we must shun. We must be clean-hearted and clean-handed in all our business transactions at home and abroad. To-dlay, with so much of the world still open for our exploitation, we have especial incentives for intelligent precautions and also for intelligent enterprise in utilizing our magnificent natural resources and of cultivating and extending the capabilities of our people. Out of Africa's hundreds of millions of imports annually we furnished only $\$ 19,000,000$ in 1906 . We sold to South America only $\$ 75,000,000$ of the $\$ 600,000,000$ of goods which she bought, and we contributed but $\$ 105,000,000$ of the $\$ \mathrm{r}, \mathrm{IO0}, 000,000$ of commodities which Asia imported from the outside world. And the volume of the imports into all these continents is rapidly expanding.

Here, my friends, some of it at our own doors, is the vast empire which lies open to us to conquer. Give us sane tariff revision in 1909; give us adequate government aid for our shipping; give our boys an industrial training in the public schools; give us harmony between employers and workers; let us combine foresight and cnterprise in the regulation of our business; let us push our trade abroad by men who have technical skill and who can talk the tongues of the countries, and we will outrun all our rivals in the race for new markets; we will make our prosperity at home permanent and balanced; and we will place our flag on all the world's seas. 